\title{
Eesti loodusainete õpetajate uskumused, õpetamispraktika ja enesetõhusus TALIS 2008 ja 2013 uuringu alusel
}

\author{
Imbi Henno ${ }^{\text {a1 }}$, Liina Kollo ${ }^{\mathrm{a}}$, Rain Mikser ${ }^{\mathrm{b}}$ \\ ${ }^{a}$ Tallinna Ülikooli loodus- ja terviseteaduse instituut \\ ${ }^{b}$ Tallinna Ülikooli haridusteaduste instituut
}

\begin{abstract}
Annotatsioon
Artiklis käsitletakse TALIS 2013 uuringus osalenud loodusainete õpetajate uskumusi, õpetamispraktikat ja enesetõhususe hinnanguid ning võrreldakse tulemusi TALIS 2008 uuringu omadega. Analüüsist selgub, et võrreldes teiste ainete õpetajatega olid loodusainete õpetajate uskumused nii TALIS 2008 kui ka TALIS 2013 uuringus konstruktivistlikumad. Kui esimeses, TALIS 2008 uuringus ei erinenud eesti ja vene õppekeelega koolide loodusainete õpetajate uskumused ja enesetõhususe hinnangud statistiliselt olulisel määral, siis teises, TALIS 2013 uuringus olid eesti õppekeelega koolide õpetajate uskumused konstruktivistlikumad, kuid enesetõhususe hinnangud madalamad. Õpetamispraktika kohta selgus, et õpilaste motiveerimist ja aktiveerimist rakendavad loodusainete õpetajad samal määral kui teiste ainete õpetajad.
\end{abstract}

Võtmesõnad: TALIS, põhikooli loodusained, õpetajate uskumused, õpetamispraktika

\section{Sissejuhatus}

Viimasel kümnendil on Eestis oluliselt täienenud arusaam õppimise ja õpetamise olemusest. Muu hulgas väljendab seda uudne õppimise käsitus, mida on eraldi paragrahvina avatud 2011. aastal vastu võetud põhikooli ja gümnaasiumi riiklikus õppekavas. Loodusainete valdkonnas, mis on praeguse artikli fookuses, on nii põhikooli kui ka gümnaasiumi riikliku õppekava loodusainete õppe eesmärk teaduslike küsimuste ja seisukohtade esitamine, teaduslike järelduste tegemine ning loodusteaduste olemuse mõistmine.

Loodus- ja terviseteaduse instituut, Tallinna Ülikool, Narva mnt 29, 10120 Tallinn; ihenno@tlu.ee 
Loomulikult eeldab nende eesmärkide saavutamine sobiva, õpilast aktiveeriva ja motiveeriva õpetamispraktika rakendamist. Seetõttu kirjutati loodusainete ainekavadesse sisse praktiliste tööde loetelud ning õppeprotsessi kirjeldustesse uurimusliku õppe tegevuste detailsed näited.

Õpetamispraktika muutumiseks ei piisa siiski üksnes asjakohaste eesmärkide ja tegevuste kirjeldamisest õppekavades või muudes haridusdokumentides. Tuleb uurida tegelikke muutusi ja küsida tagasisidet. Et saada kvaliteetseid ja võrreldavaid andmeid õpilaste õppimise ja õpetajate õpetamispraktika kohta, on Eesti osalenud OECD rahvusvahelises õpilaste hindamise võrdlusuuringus PISA (Program for International Student Assessment) ning õpetamise ja õppimise uuringus TALIS (The Teaching and Learning International Survey). Eesti õpilased on olnud PISA uuringutes väga edukad (OECD, 2007, 2010a, 2013a, 2016), jõudes 2015. aastal loodusainetes rahvusvahelisel tasandil kolmandale kohale. Teiste PISA hindamisvaldkondadega (lugemine ja matemaatika) võrreldes ongi Eesti õpilased olnud kõige edukamad nimelt loodusainetes. Samas on varasemad uuringud ning sekundaaranalüüsid toonud esile loodusainete õpetamisega seotud probleemid. Üldjoontes võib eristada kolme liiki probleeme:

1) suured erinevused eesti ja vene õppekeelega koolide õpilaste sooritustes eesti õppekeelega koolide õpilaste tulemused on kõigis uuringutes olnud oluliselt paremad (Henno, 2016);

2) tippsooritajate vähesus (hoolimata asjaolust, et PISA 2006. ja 2015. aasta uuringu võrdluses on olukord paranenud - vt OECD 2016);

3) õpilaste vähene motivatsioon õppida tulevikus loodusteadusi.

Nende probleemide tõttu ei saa riiklikus õppekavas loodusainetele seatud eesmärkide puhul saavutatuga täielikult rahul olla. Põhjusi selleks on mitu, ent vähemalt osaliselt taanduvad need õpetajate uskumustele, õpetamispraktikale ja enesetõhususele. PISA uuringute sekundaaranalüüsid näitavad, et eri õppekeelega koolide õpilaste soorituserinevused ning tippsooritajate vähesus Eestis ei sõltu niivõrd haridussüsteemist, koolist või õpilasest, kuivõrd eelkõige õpetajate õpetamispraktikast. Nii eesti kui ka vene õppekeelega koolide loodusainete tundides tähtsustatakse ainesisu, harva rakendatakse uurimuslikku õpet (Henno, 2015). Seejuures domineerib just vene õppekeelega koolides pigem õpetajakeskne õpetamine (Loogma, Ruus, Talts, \& Poom-Valickis, 2009; Ruus et al., 2007; Säälik, 2012).

Õpetamispraktika ümberkujundamiseks on loodusainete õpetajatele koostatud palju metoodilisi juhendmaterjale ning korraldatud täiendkoolitusi. Kuigi need mõjuvad positiivselt, muutuvad õpetamistavad väga aeglaselt (Laius, Rannikmäe, \& Yager, 2008; Laius, Kask, \& Rannikmäe, 2009; Laius \& Rannikmäe, 2011). Seega ei piisa õpetamispraktika muutumiseks 
üksnes õpetajate lisanduvatest teadmistest - arvestada tuleb ka õpetajate uskumusi (Vaino, 2013). Nimelt on uskumused oluline uurimisteema, kuna need võivad pärineda üsna kaugest minevikust, õpetaja karjääri algusaegadest, olles saanud õpetaja identiteedi osaks ning takistades seetõttu lisandunud teadmiste omaksvõttu (Goodson, Moore, \& Hargreaves, 2006). Uskumuste rakendamist praktikas - ka juhul, kui need on uusimate teaduslike teadmiste seisukohalt põhjendatud - mõjutab omakorda õpetaja enesetõhusus. See termin märgib usku oma võimesse teha midagi, millele järgnevad teatud saavutused (Bandura, 1997). Rahvusvahelised uuringud on näidanud, et õpetaja suurem enesetõhusus mõjutab positiivselt tema valmisolekut rakendada uudset, ka keerukat praktikat (Ross, 1998; Ross \& Bruce, 2007), samuti valmisolekut õpilasi aktiveerida ning edendada nende autonoomiat (Ross \& Bruce, 2007). Seega on oluline uurida ka õpetaja enesetõhusust.

Artikli eesmärk on tutvustada analüüsi, milles püüdsime TALIS 2008 ja TALIS 2013 tulemusi võrreldes selgitada, kas ja kuidas on loodusainete õpetajate uskumused, õpetamispraktika ning enesetõhususe hinnangud viimastel aastatel muutunud. See teadmine võimaldab hinnata loodusainete õpetajate senise põhi- ja täiendõppe tõhusust, arendada õpetajate uskumusi teadlikult, juurutada tõhusamat õpetamispraktikat ning seeläbi toetada nii eesti kui ka vene õppekeelega koolide õpilaste võimete arengut ja suurendada motivatsiooni tegelda tulevikus loodusteadustega.

Tuginedes TALIS 2008 tulemustele ja PISA uuringutest ilmnenud probleemidele, püstitasime järgmised hüpoteesid:

1) võrreldes teiste ainete õpetajatega on loodusainete õpetajate uskumused konstruktivistlikumad (mis vähemalt osalt seletab õpilaste erilist edu loodusainetes PISA testide põhjal);

2) loodusainete õpetajate enesetõhususe hinnangud on teiste õpetajate hinnangutega samaväärsed;

3) eesti ja vene õppekeelega koolide loodusainete õpetajate uskumused ja enesetõhususe hinnangud on sarnased;

4) võrreldes teiste õpetajatega pööravad loodusainete õpetajad suuremat tähelepanu õpilasi aktiveeriva praktika rakendamisele.

Võib oletada, et tippsooritajate vähene osakaal, õpilaste väike motivatsioon ja vene õppekeelega koolide kehvemad tulemused on seotud õpetajate uskumuste, enesetõhususe hinnangute ja õpetamispraktikaga. Tippude vähesus võib olla seotud sellega, et enamasti rakendatakse struktureeritud õpetamist ja harva uurimuslikku õpet. 


\section{Teoreetiline taust}

\section{Konstruktivism õppimise, õpetamise ja uurimusliku õppe teoreetilise alusena}

Nagu teada, mõjutab õpetajate õpetamispraktika õpilaste motivatsiooni ja õpitulemusi (Kunter et al., 2013). Juba aastakümneid peetakse õpilaste motiveerimise ja sisemise aktiveerimise seisukohalt kõige tõhusamaks sellist praktikat, mis põhineb konstruktivistlikel õpiteooriatel, sest seda seostatakse õpilase motivatsiooniga ja paremate õpitulemustega (Vieluf, Kaplan, Klieme, \& Bayer, 2012). Konstruktivistlikud uskumused (ingl constructivist beliefs) õppimise ja õpetamise kohta on ka üks TALISe uuringu teoreetilistest alustaladest, seega on oluline käsitleda konstruktivismi ja konstruktivistlike uskumuste potentsiaalset seost parima õpetamispraktikaga. Siinses alapeatükis vaadeldakse konstruktivistliku õppimise ja õpetamise eeliseid ning piiranguid.

Konstruktivistlikud õppimis- ja õpetamisteooriad kasvasid välja eelkõige Jean Piaget' (1952), Lev Võgotski (1978) ja Jerome Bruneri (1960, 1961) käsitlustest. Need autorid rõhutavad, et õppimine peab olema õppija jaoks tähenduslik. Sellel arusaamal põhinevad avastusõpe, uurimuslik õpe ja praktiline õpe (Duffy \& Jonassen, 1992). Bruneri (1961) järgi on õppimine tulemuslik, kui õpilased on sisemiselt motiveeritud - õppimine on edukaim avastusõppena. Bruneri tööd muutsid loodusainete õpetamist paljudes riikides. Aja jooksul nihkus rõhk avastuste tegemiselt õppimisele kui uurimuslikule protsessile (Duffy \& Jonassen, 1992).

Tähelepanu konstruktivistlikule õppele suurenes 1990. aastatel, mil uurimuslikku õpet hakati kujutama õpetamise peavooluna. 1996. aastal kirjutati uurimuslik õpe USA haridusstandardisse (National Research Council, 1996). Uuringud on näidanud, et uurimuslik õpe parandab õpilaste akadeemilist sooritust, loodusteaduslikke hoiakuid ning kriitilist mõtlemist (Blanchard, Freiman, \& Lirrete-Pitre, 2010; Furtak, Seidel, Iverson, \& Briggs, 2012; Hattie, 2009; Kobarg et al., 2011; Seidel \& Scheerens, 2005). Seetõttu kirjeldatakse ka loodusteaduslikku uurimuslikku õpet konstruktivistliku protsessina (Bybee, 2006).

\section{Konstruktivismi suhe struktureeritud õppega}

Viimaste kümnendite uurimustest ilmneb, et konstruktivistlikust käsitlusviisist üksi ei piisa, et soodustada õppimist (Kirschner, Sweller, \& Clark 2006; Mayer, 2004, 2009). Mayer (2004) eristab tegevuslikku aktiivsust, mis soodustab õppimist suhteliselt vähe, ning kognitiivset aktiivsust, mis 
soodustab õppimist märksa enam ja kinnistab õpitut pikaajalises mälus. Õppija peab olema õppides kognitiivselt aktiivne, mitte ainult $n$-ö avastama ning õpetamine peab olema juhendatud ehk struktureeritud (Mayer, 2004, 2009). Ka teised uurijad rõhutavad, et praktiliste tööde tegemine toetab õppimist vaid juhul, kui see on hästi läbimõeldud ja struktureeritud ning kui õpilased on kognitiivselt aktiveeritud (Hofstein \& Lunetta, 2004). Kirschner jt (2006) väidavad, et konstruktivistlik õpetamine ei sobi algajaile, vaid eelkõige teadlikematele õpilastele. Õpilastega, kel on vähe eelteadmisi või need puuduvad üldse, tuleb esmalt rakendada struktureeritud tegevusi.

Teisedki uurijad rõhutavad, et paremate kognitiivsete tulemuste saavutamiseks on olulised tunni struktureeritus ning õppetöö hea korraldus (Baumert et al., 2010; Creemers \& Kyriakides, 2008; Vieluf et al., 2012). Sellise õpetamise oluliseks aluseks on Bloomi (1976) õppematerjali täieliku omandamise (mastery learning) mudel, mille kohaselt ei lähe õppija järgmise teema juurde enne, kui eelmine teema on vähemalt $80 \%$ ulatuses omandatud. Sellist õpetamist - otsest juhendamist - iseloomustab õpetuse selge eesmärk, óppematerjali järkjärguline esitamine, õpilaste sage küsitlemine ning arengu jälgimine (Brophy \& Good, 1986).

Samamoodi nagu teiste õpetamismeetodite puhul, sõltub ka struktureeritud õpetamise meetodi tõhusus sellest, kui läbimõeldult seda kasutatakse. Seidel ja Scheerens (2005) leiavad, et õpetamise mõju seostub võrdselt nii konstruktivistliku kui ka struktureeritud õpetamisega. Aktiveeriv ja struktureeritud õpetamine, konstruktivistlik õpikäsitlus ja õpilastele orienteeritus, kuid ka õppeprotsessi kavakindel juhtimine õpetaja poolt on omavahel seotud (Vieluf et al., 2012).

Eelnevate alapeatükkide eesmärk oli teoreetiliste käsitluste abil näitlikustada, et parimate õpetamistavade juurutamiseks ei ole oluline mitte konstruktivismi ühekülgne ületähtsustamine, vaid selle teadlik ja olutundlik rakendamine õpilaste motiveerimiseks ning kognitiivseks aktiveerimiseks.

\section{Loodusainete õpetamine ja PISA uuringud - uurimuslik versus struktureeritud õpe}

PISA 2015 uuringu rõhuasetus oli loodusteadustel. Selle uuringu üks põhijäreldusi oli, et õppematerjalide kvaliteet, praktilise töö vahendite kättesaadavus ning loodusteadustega seotud praktilised tegevused mõjutavad õpitulemusi vähem kui loodusainete õppimisele pühendatud aeg ning eriti viis, kuidas loodusaineid õpetatakse. Õpilased saavutasid loodusainetes paremaid tulemusi, kui nende väitel kasutasid õpetajad nii struktureeritud kui ka individualiseerivat õpetamispraktikat, samuti uurimuslikku õpet 
(viimast eelkõige eesmärgiga kujundada õpilaste arusaamist teaduse olemusest ning loodusteadustega seotud karjäärivalikuid) (OECD, 2016). Siinkohal tuleb rõhutada, et PISA 2006 uuringus, mis keskendus samuti loodusteadustele, ei analüüsitud sellist õpetamispraktikat nagu otsene juhendamine või struktureeritud õpetamine. Õpetamispraktikat hinnati ainult konstruktivistliku õpikäsitusega seotud indeksite abil.

PISA 2015 uuringus mõõdeti detailselt, kuidas mõjutab uurimusliku õppe rakendamine õpitulemusi. Mõneti üllatavalt selgus, et mitte üheski haridussüsteemis, kus õpilaste väitel rakendatakse uurimuslikku õpet sagedamini, ei saadud loodusteadustes paremaid tulemusi (OECD, 2016). Eesti õpilaste tagasisidest nähtub, et koolides rakendati praktilisi tegevusi ja uurimuslikku õpet harva. Vaid 9\% Eesti õpilastest (OECD keskmine 21\%) väitis, et nad käivad sageli laboris või teevad katseid. Selle näitaja poolest oli Eesti riikide pingerea lõpus (tagantpoolt 6. koht).

Uurimusliku õppe vähesus võib osalt seletada põhjusi, miks Eestis on vähe tippsooritajaid. Eesti uuringud näitavad, et kuigi Eesti loodusainete õpetajad tähtsustavad 2011. aasta riiklike õppekavade konstruktivistlikku õpikäsitust, praktilisi tegevusi ja uurimuslikku õpet, ei plaaninud nad õppekavu rakendades muuta oma õpetamispraktikat ega pöörata enam tähelepanu õpilaste karjääriteadlikkuse kujundamisele (Henno \& Granström, 2012). PISA 2006 sekundaaranalüüsid kinnitavad, et Eesti 15aastastel õpilastel oli väike huvi õppida tulevikus loodusteadusi (Henno, 2010). Sama ilmnes gümnasistide puhul (Kollo, 2016; Lond, 2010; Soobard \& Rannikmäe, 2014). Seega vajab loodusainete õpetamine Eestis paradigmamuutust, et õpetajad hakkaksid enam rakendama õpilaskeskseid, sotsiaalse suunitlusega ning probleemide lahendamisele keskenduvat õpetamispraktikat (Holbrook, 2008; Rannikmäe, 2008).

\section{TALIS: õpetajate uskumused, õpetamispraktika ja enesetõhusus}

Teavet õpetamise kohta kogutakse TALISe uuringuga, kuna PISA uuring ei võimalda õpilase sooritust siduda tema õpetaja õpetamispraktikaga. Praeguse analüüsi seisukohalt oluliste komponentidena mõõdetakse TALISe uuringuga õpetajate uskumusi (beliefs), õpetamispraktikat (teaching practices) ning enesetõhusust (self-efficacy) (OECD, 2010b).

\section{Uskumused}

Et selgitada õpetajate uskumusi, konstrueeriti Petersoni jt (1989) õpetajate uskumuste uuringule tuginedes TALIS 2008 uuringus kaks standardiseeritud koondtunnust ehk indeksit: a) traditsioonilised uskumused; 
b) konstruktivistlikud uskumused (OECD, 2010b). Üldistatult vastavad viimased eespool kirjeldatud konstruktivismi põhimõtetele.

TALIS 2008 uuringust ilmnes, et võrreldes teiste ainete õpetajatega olid loodusainete õpetajate uskumused konstruktivistlikumad (OECD, 2010b). Ka TALIS 2013 uuring näitas, et osalenud riikide, sealhulgas Eesti õpetajatel olid õppimise ja õpetamise olemuse kohta enamasti konstruktivistlikud uskumused (OECD, 2014a). Eesti õpetajate uskumused olid osalenud riikide õpetajate hulgas ühed kõige konstruktivistlikumad (Loogma et al., 2009).

\section{Õpetamispraktika}

Õpetajate õpetamispraktika selgitamiseks moodustati TALIS 2008 uuringus, tuginedes Klieme, Lipowsky, Rakoczy ja Ratzka (2006) õpetamismudelile, kolm õpetamise indeksit: a) struktureeritud õpetamine (otsesed juhised); b) ópilastele orienteeritud ópetamine (õpilast toetav kliima ja individuaalne juhendamine); c) kognitiivne aktiveerimine (kõrgema tasandi mõtlemisoskusi kujundavad jm nõudlikud ülesanded) (OECD, 2010b). Teiste TALISe uuringus osalenud riikide õpetajatega võrreldes rakendasid nii eesti kui ka vene õppekeelega koolide loodusainete õpetajad eelnimetatud kolme dimensiooni hulgast enim struktureeritud praktikat ning vähem õpilaste kõrgema tasandi mõtlemisoskuste kujundamise praktikat (Henno, 2015). Loodusainete õpetajad (nagu ka matemaatika- ja võõrkeeleõpetajad) rakendasid kõige harvem õpilaste kognitiivse aktiveerimise praktikat (OECD, 2010b).

Erinevalt 2008. aasta uuringust ei mõõtnud TALIS 2013 uuring õpetamist eraldi koondtunnustega. Õpetajaid võrreldi üksikküsimuste kaupa. Õpetamispraktikat kirjeldati kas passiivse või aktiveerivana. Kui õpetajad rakendasid praktikat, kus õpilasel oli õppeprotsessis keskne osa, loeti see aktiveerivaks praktikaks. Kui domineeris loeng ning õpilased olid vähe kaasatud, liigitati see passiivse praktika alla (OECD, 2014a). TALIS 2013 uuring näitas, et aktiveerivate meetodite kasutamine sõltus õppeainest. Võrreldes teiste ainete õpetajatega rakendasid loodusainete (samuti matemaatika ja humanitaarainete) õpetajad aktiveerivaid meetodeid vähem (OECD, 2014a).

Nagu nähtub, on Eesti loodusainete õpetajate ülekaalukalt konstruktivistlikud uskumused vastuolus nende õpetamispraktikaga, mis on valdavalt struktureeritud ning õpilasi kognitiivselt vähe aktiveerivad. Kikas (2013), püüdes seda olukorda selgitada, osutab kahele aspektile. Esiteks, õpetajad küll usuvad, et konstruktivism on õige ning seda tuleb rakendada, kuid 
neid takistab seda reaalselt tegemast väidetav õppekava ülekoormatus. Teiseks ei pruugi õpetaja ettekujutus konstruktivismist olla kooskõlas tema varasemate teadmiste ja uskumustega, mistõttu ta jätkab traditsiooniliste meetodite rakendamist, kuigi võib sõnades konstruktivismi tähtsustada (ibid.).

\section{Õpetaja enesetõhusus kui uskumusi ja õpetamispraktikat mõjutav faktor}

Õpilast kognitiivselt aktiveeriva praktika rakendamine eeldab professionaalset ning oma tegevuse õigsuses veendunud õpetajat. Õpetaja professionaalsuse üks näitaja on õpetaja enesetõhusus (Klassen, Tze, Betts, \& Gordon, 2011; Ross \& Bruce, 2007).

TALIS 2008 võrdlusanalüüs näitas, et Eesti õpetajad olid riikide võrdluses ühed kõige madalama enesetõhususe hinnanguga. Sekundaaruuringu järgi ei ilmnenud eesti ja vene õppekeelega koolide loodusainete õpetajate enesetõhususes, samuti uskumustes TALIS 2008 uuringu põhjal statistiliselt olulist erinevust (Henno, 2015). Samas uskusid eesti õppekeelega koolide õpetajad vähem teadmiste otsese ülekande võimalusse.

TALIS 2013 mõõtis õpetajate enesetõhusust kolme indeksiga ehk koondtunnusega: a) klassikorra (distsipliini) hoidmine; b) õpetamine; c) õpilaste juhendamine ja motiveerimine. Eesti vastavad näitajad olid TALIS 2013 keskmistest kõrgemad distsipliini hoidmisel, ent ühed madalamad õpetamises (Übius, Kall, Loogma, \& Ümarik, 2014).

Püüdes selgitada, millised muutused on viimastel aastatel toimunud loodusainete õpetajate uskumustes, õpetamispraktikas ning enesetõhususes, tegime TALIS 2008 ja TALIS 2013 andmete sekundaaranalüüsi ning võrdlesime tulemusi nii enda kui ka teiste Eesti uurijate varasemate analüüsidega, samuti TALIS 2008 lõppraporti järeldustega. Eesti-siseste trendide kirjeldamiseks võrdlesime loodusainete õpetajate uskumusi ja õpetamispraktikat teiste ainete õpetajate vastustega.

\section{Metoodika}

Artikli aluseks on kirjeldav kvantitatiivne uuring, mis tugineb TALIS 2008 ja TALIS 2013 uuringu andmete sekundaaranalüüsile.

\section{Valim}

TALIS 2008 ja TALIS 2013 uuringu Eesti õpetajate valimid olid esinduslikud. Valimi moodustasid põhikooli III astme (7.-9. klassi) õpetajad. 
TALIS 2008 uuringus osales juhuvalimi alusel 3321 õpetajat 198 koolist. Õpetajatest, kes olid loodusteadusliku haridusega ja märkisid õpetatavatest ainetest põhiaineteks loodusained, moodustati eraldi tunnus loodusainete ópetaja $(18,0 \%, N=598)$. Neist $85,8 \%(N=513)$ õpetas eesti õppekeelega koolis ja 14,2\% $(N=85)$ vene õppekeelega koolis. TALIS 2013 uuringus osales juhuvalimi alusel 3129 õpetajat 197 koolist. 837 (27,3\%) õpetajat, kel oli magistrikraad loodusteadustes ja kes töötasid õpetajatena, moodustasid tunnuse loodusainete ópetaja. Neist 79,5\% $(N=665)$ õpetas eesti õppekeelega koolis, 9,8\% $(N=82)$ vene õppekeelega koolis ning 10,8\% $(N=90)$ nii eesti kui ka vene õppekeelega koolis.

Õpetajate arv Eestis oli EHISe andmetel 2007/2008. õppeaastal 15039 ja 2012/2013. õppeaastal 14 263. Seega kuulus mõlema uuringu valimisse $22 \%$ Eesti õpetajaskonnast.

\section{Mõõtevahendid}

Eesti loodusainete õpetajate pedagoogiliste uskumuste ja õpetamispraktika analüüsis kasutati TALIS 2008 ja TALIS 2013 andmebaasi üksikküsimusi ja koondtunnuseid ehk indekseid. TALISe uuringus moodustati õpetajate taustaküsimustike hinnangute põhjal erinevaid indekseid. Need on väljendatud OECD keskmisele tulemusele standardiseeritud skaala indeksitena (weighted likelihood estimates, keskmine 0, standardhälve 1) (OECD, 2009). TALISe uuringute indeksite detailsed kirjeldused leiab OECD raportitest (OECD, 2010b, 2014b).

Uskumuste kohta käivatele küsimustele vastamisel paluti õpetajatel nõustumise astme väljendamiseks märkida üks järgmistest vastusevariantidest: nõustun täielikult, nõustun, eriti ei nõustu, üldse ei nõustu. Õpetamispraktika sageduse kirjeldamisel olid variantideks mitte kunagi, harva, sageli, peaaegu iga tund või üldse mitte, mõningal määral, vahel, sageli (OECD, 2010b, 2014b).

Esmalt võrdlesime TALIS 2008 uuringu põhjal loodusainete ja teiste ainete õpetajate hinnanguid. Seejärel kaasasime analüüsi TALIS 2013 uuringus osalenud loodusainete õpetajate enesetõhusust, uskumusi ja õpetamispraktikat kirjeldavad üksikväited $(N=28)$ ning koondtunnused ehk indeksid.

Siinses analüüsis kasutasime õpetajate uskumuste ja õpetamispraktika indekseid, mille olid TALIS 2008 korraldajad keskselt kogu uuringu jaoks moodustanud. Neid indekseid oli kokku seitse: 1) enesetõhusus; 2) teadmiste ülekandmine; 3) konstruktivistliku ópetamise uskumus; 4) struktureeritud õpetamine; 5) ópilastele orienteeritud ópetamine ja 6) kõrgema tasandi 
mõtlemisoskusi kujundav õpetamine. TALIS 2013 uuringu tarbeks moodustatud indeksitest kaasasime analüüsi järgmised: 1) enesetõhusus ópetamisel; 2) enesetõhusus ópilaste juhendamisel ja motiveerimisel ning 3) konstruktivistlikud uskumused (OECD, 2014b).

Siinkohal tuleb arvestada, et TALIS 2013 uuringus ei moodustatud 2008. aasta uuringuga sarnaseid õpetamispraktika indekseid, vaid üldistused tehti üksikküsimuste kaupa. Analüüsis kasutati järgmisi TALIS 2013 väiteid aktiveeriva praktika kohta: 1) oppilased töötavad väikestes rühmades, et lahendada ühiselt probleem või ülesanne; 2) opilased töötavad projektidega, mille teostamiseks kulub vähemalt nädal ja 3) ópilased kasutavad IKT-vahendeid projektide või klassitöö jaoks (OECD, 2014b).

2008. ja 2013. aasta uuringute indeksitest on otseselt võrreldavad konstruktivistliku uskumuse indeksid, sest mõlemas uuringus olid selle indeksi alaküsimused samad. Analüüsis kasutati järgmisi uskumustealaseid väiteid, millega nõustumine tähendab, et uskumust võib pidada konstruktivistlikuks: 1) minu roll ópetajana on toetada ópilaste enda uurimistegevust;2) kõige paremini õpivad ôpilased siis, kui leiavad iseseisvalt probleemidele lahendusi; 3) ópilastel peaks võimaldama mõelda ise lahenduste üle ning 4) mõtlemine ja järelduste tegemine on tähtsam kui ainekava konkreetne sisu.

Enesetõhususe analüüsimisel kasutati järgmisi TALIS 2013 väiteid (OECD, 2014b), mis olid seotud enesetõhususega õpetamisel: 1) töötan õpilaste jaoks välja head küsimused; 2) kasutan erinevaid hindamisstrateegiaid; 3) pakun alternatiivseid seletusi, kui oppilased on segaduses ning 4) rakendan tunnis alternatiivseid õpetamisstrateegiaid. Enesetõhusus õpilaste motiveerimisel ja juhendamisel väljendus järgmistes väidetes: 1) kujundan õpilaste eneseusku sellesse, et nad saavad koolis hästi hakkama; 2) aitan õpilastel väärtustada óppimist; 3) motiveerin ópilasi, kellel on vähene huvi koolitööde vastu ja 4) aitan ópilastel kriitiliselt mõelda.

Õpetajate hinnangute statistikute arvutamiseks kasutasime sagedustabeleid ja $\chi^{2}$-testi. Rühmadevahelised keskmised ja hajuvuse selgitasime välja $t$-testi või ANOVA (one-way) abil. Tunnustevahelisi seoseid pidasime statistiliselt oluliseks, kui olulisuse tõenäosuse $p$-väärtus oli väiksem kui 0,05 (5\%). Kuna valim oli esinduslik ja andmeanalüüs põhineb kaalutud valimil, saab üldistusi teha kogu Eesti loodusainete õpetajaskonna kohta. 


\section{Tulemused}

\section{Loodus- ja teiste ainete ning eesti ja vene õppekeelega koolide loodusainete õpetajate uskumused ning õpetamispraktika}

Esmalt võrdlesime TALIS 2008 uuringu põhjal loodusainete ja teiste ainete õpetajate hinnanguid uskumuste, enesetõhususe ja õpetamispraktika kohta. Enesetõhususe ning õpilastele orienteeritud ja kõrgema tasandi mõtlemisoskusi kujundava praktika puhul olid loodusainete õpetajate hinnangud teistest madalamad. Seevastu konstruktivistlike uskumuste ja struktureeritud õpetamise kategooriates oli nende nõustumise määr kõrgem. Teadmiste otsese ülekandmise kohta antud hinnangutes puudus loodusainete õpetajate ja teiste ainete õpetajate vahel statistiliselt oluline erinevus (tabel 1).

Tabel 1. TALIS 2008 uuringus osalenud Eesti loodusainete (LÕP) ja teiste ainete õpetajate (TÕP) uskumuste, õpetamispraktika ning enesetõhususe hinnangud

\begin{tabular}{|c|c|c|c|c|c|c|}
\hline Indeks & $\begin{array}{l}\text { Õpeta- } \\
\text { jad }\end{array}$ & $N$ & $\begin{array}{l}\text { Kesk- } \\
\text { väärtus }\end{array}$ & $\begin{array}{l}\text { Standard- } \\
\text { hälve }\end{array}$ & $t$ & $\begin{array}{c}p \text { - } \\
\text { väärtus }\end{array}$ \\
\hline \multirow[t]{2}{*}{ Enesetõhusus } & LÕP & 2508 & $-0,46$ & 0,70 & \multirow{2}{*}{5,76} & \multirow{2}{*}{0,016} \\
\hline & TÕP & 598 & $-0,39$ & 0,64 & & \\
\hline \multirow{2}{*}{$\begin{array}{l}\text { Konstruktivistliku } \\
\text { õpetamise uskumus }\end{array}$} & LÕP & 2501 & 0,48 & 0,79 & \multirow{2}{*}{9,56} & \multirow{2}{*}{0,002} \\
\hline & TÕP & 597 & 0,37 & 0,78 & & \\
\hline \multirow{2}{*}{$\begin{array}{l}\text { Teadmiste otsese } \\
\text { ülekandmise uskumus }\end{array}$} & LÕP & 2501 & $-0,99$ & 0,69 & \multirow{2}{*}{0,34} & \multirow{2}{*}{0,557} \\
\hline & TÕP & 597 & $-1,01$ & 0,69 & & \\
\hline \multirow{2}{*}{$\begin{array}{l}\text { Kõrgema tasandi } \\
\text { mõtlemisoskusi } \\
\text { kujundav praktika }\end{array}$} & LÕP & 2481 & $-0,44$ & 0,67 & \multirow{2}{*}{13,85} & \multirow{2}{*}{0,000} \\
\hline & TÕP & 593 & $-0,37$ & 0,65 & & \\
\hline \multirow{2}{*}{$\begin{array}{l}\text { Struktureeritud } \\
\text { õpetamispraktika }\end{array}$} & LÕP & 2481 & $-0,09$ & 0,79 & \multirow{2}{*}{10,19} & \multirow{2}{*}{0,001} \\
\hline & TÕP & 593 & $-0,22$ & 0,93 & & \\
\hline \multirow{2}{*}{$\begin{array}{l}\text { Õpilasele orienteeritud } \\
\text { praktika }\end{array}$} & LÕP & 2481 & $-0,38$ & 0,76 & \multirow{2}{*}{14,13} & \multirow{2}{*}{0,000} \\
\hline & TÕP & 593 & $-0,25$ & 0,77 & & \\
\hline
\end{tabular}

Allikas: OECD TALIS 2008 andmebaas, autorite arvutused, $t$-test

Kuna eri õppekeelega koolide loodusainete õpetajate uskumuste, õpetamispraktika ja enesetõhususe hinnanguid on TALIS 2008 uuringu põhjal varem analüüsitud (Henno, 2015), siis analüüsiti järgnevalt TALIS 2013 uuringu loodusainete õpetajate hinnanguid.

TALIS 2008 ja TALIS 2013 uuringus kattusid õpetajate uskumuste ja õpetamispraktika taustaküsimused ning koondtunnused vaid väikeses osas. 
Seetõttu võrreldi $\chi^{2}$-testi kasutades kõigepealt TALIS 2013 õpetajate hinnanguid üksikküsimuste kaupa. Kokku kaasati analüüsi 28 küsimust enesetõhususe, õpilastele orienteerituse ja konstruktivistliku uskumuse kohta. Üheksa küsimuse vastustes ilmnes loodusainete ja teiste ainete õpetajate hinnangute vahel statistiliselt oluline erinevus (tabel 2).

Tabel 2. TALIS 2013 uuringus osalenud Eesti loodusainete ja teiste ainete õpetajate uskumuste, õpetamispraktika ja enesetõhususega seotud väidete võrdlus

\begin{tabular}{|c|c|c|c|c|c|}
\hline Väide & $\begin{array}{l}\text { Nõustumine / } \\
\text { hinnang } \\
\text { sagedusele }\end{array}$ & $\begin{array}{c}\text { Loodusainete } \\
\text { õpetajad } \\
N\end{array}$ & $\begin{array}{c}\text { Teised } \\
\text { õpetajad } \\
N\end{array}$ & $\begin{array}{c}X^{2}- \\
\text { statistik }\end{array}$ & $\begin{array}{c}p- \\
\text { väärtus }\end{array}$ \\
\hline \multirow{2}{*}{$\begin{array}{l}\text { Minu roll õpetajana } \\
\text { on toetada õpilaste } \\
\text { enda uurimis- } \\
\text { tegevust }\end{array}$} & $\begin{array}{l}\text { Ei ole nõus / } \\
\text { üldse ei nõustu }\end{array}$ & $40(4,8 \%)$ & $131(6,0 \%)$ & \multirow{2}{*}{10,074} & \multirow{2}{*}{0,018} \\
\hline & $\begin{array}{l}\text { Nõustun / } \\
\text { nõustun täielikult }\end{array}$ & $786(95,2 \%)$ & $2056(94,0 \%)$ & & \\
\hline \multirow{2}{*}{$\begin{array}{l}\text { Töötan õpilaste } \\
\text { jaoks välja head } \\
\text { küsimused }\end{array}$} & $\begin{array}{l}\text { Üldse mitte / } \\
\text { mõningal määral }\end{array}$ & $172(21,0 \%)$ & $619(28,4 \%)$ & \multirow{2}{*}{18,041} & \multirow{2}{*}{0,000} \\
\hline & Vahel/sageli & $648(79,0 \%)$ & $1557(71,6 \%)$ & & \\
\hline \multirow{2}{*}{$\begin{array}{l}\text { Motiveerin õpilasi, } \\
\text { kellel on vähene huvi } \\
\text { koolitööde vastu }\end{array}$} & $\begin{array}{l}\text { Üldse mitte / } \\
\text { mõningal määral }\end{array}$ & $213(25,8 \%)$ & $533(24,5 \%)$ & \multirow[t]{2}{*}{8,232} & \multirow[t]{2}{*}{0,041} \\
\hline & Vahel/sageli & $611(74,2 \%)$ & $1647(75,6 \%)$ & & \\
\hline \multirow[t]{2}{*}{$\begin{array}{l}\text { Kujundan õpilaste } \\
\text { kriitilist mõtlemist }\end{array}$} & $\begin{array}{l}\text { Üldse mitte / } \\
\text { mõningal määral }\end{array}$ & $186(22,7 \%)$ & $574(26,4 \%)$ & \multirow[t]{2}{*}{9,769} & \multirow[t]{2}{*}{0,021} \\
\hline & Vahel/sageli & $635(77,3 \%)$ & $1604(73,6 \%)$ & & \\
\hline \multirow{2}{*}{$\begin{array}{l}\text { Pakun alternatiivseid } \\
\text { seletusi, kui õpilased } \\
\text { on segaduses }\end{array}$} & $\begin{array}{l}\text { Üldse mitte / } \\
\text { mõningal määral }\end{array}$ & 159 (19,3\%) & $506(23,2 \%)$ & \multirow[t]{2}{*}{8,908} & \multirow[t]{2}{*}{0,031} \\
\hline & Vahel/sageli & $664(80,7 \%)$ & $1672(76,8 \%)$ & & \\
\hline \multirow{2}{*}{$\begin{array}{l}\text { Rakendan tunnis } \\
\text { alternatiivseid } \\
\text { õpetamis- } \\
\text { strateegiaid }\end{array}$} & $\begin{array}{l}\text { Üldse mitte / } \\
\text { mõningal määral }\end{array}$ & $302(36,7 \%)$ & $908(41,7 \%)$ & \multirow{2}{*}{8,311} & \multirow{2}{*}{0,040} \\
\hline & Vahel/sageli & $522(63,3 \%)$ & $1267(58,3 \%)$ & & \\
\hline \multirow[t]{2}{*}{$\begin{array}{l}\text { Teen kokkuvõtte } \\
\text { hiljuti õpitu sisust }\end{array}$} & $\begin{array}{l}\text { Harva / } \\
\text { mitte kunagi }\end{array}$ & $111(15,8 \%)$ & $399(21,2 \%)$ & \multirow{2}{*}{13,007} & \multirow{2}{*}{0,005} \\
\hline & $\begin{array}{l}\text { Sageli / } \\
\text { peaaegu iga tund }\end{array}$ & $593(84,2 \%)$ & $1485(78,8 \%)$ & & \\
\hline \multirow{2}{*}{$\begin{array}{l}\text { Annan ülesandeid, } \\
\text { mis näitavad, miks } \\
\text { uus teadmine või } \\
\text { oskus on vajalik } \\
\text { igapäevaelu või töö } \\
\text { jaoks }\end{array}$} & $\begin{array}{l}\text { Harva / } \\
\text { mitte kunagi }\end{array}$ & $243(34,6 \%)$ & $783(41,8 \%)$ & \multirow[b]{2}{*}{13,858} & \multirow[b]{2}{*}{0,003} \\
\hline & $\begin{array}{l}\text { Sageli / } \\
\text { peaaegu iga tund }\end{array}$ & $459(65,4 \%)$ & $1090(58,2 \%)$ & & \\
\hline
\end{tabular}




\begin{tabular}{l|l|c|c|c|c}
\hline Väide & $\begin{array}{l}\text { Nõustumine / } \\
\text { hinnang } \\
\text { sagedusele }\end{array}$ & $\begin{array}{c}\text { Loodusainete } \\
\text { oppetajad } \\
N\end{array}$ & $\begin{array}{c}\text { Teised } \\
\text { opetajad } \\
N\end{array}$ & $\begin{array}{c}X^{2} \text { - } \\
\text { statistik }\end{array}$ & $\begin{array}{c}p \text { - } \\
\text { väärtus }\end{array}$ \\
\hline $\begin{array}{l}\text { Kontrollin õpilaste } \\
\text { töövihikuid või } \\
\text { koduseid töid }\end{array}$ & $\begin{array}{l}\text { Harva / } \\
\text { mitte kunagi }\end{array}$ & $194(27,8 \%)$ & $565(30,2 \%)$ & \multirow{2}{2}{20,779} & 0,000 \\
\cline { 2 - 4 } & $\begin{array}{l}\text { Sageli / } \\
\text { peaaegu iga tund }\end{array}$ & $503(72,2 \%)$ & $1306(69,8 \%)$ & \\
\hline
\end{tabular}

Allikas: OECD TALIS 2013 andmebaas, autorite arvutused, $\mathrm{x}^{2}$-test

Kaheksa küsimuse puhul olid statistiliselt oluliselt kõrgemad just loodusainete õpetajate hinnangud ja nõustumise määrad, nt õpilaste uurimistegevuse toetamises ning õpilaste kriitilise mõtlemise kujundamises. Samas oli väite Motiveerin õpilasi, kellel on väike õpimotivatsioon puhul loodusainete õpetajate nõustumise määr hoopis madalam (tabel 2).

$T$-testi kasutati selleks, et võrrelda (kahes grupis) indekseid enesetõhusus õpetamisel, enesetõhusus õpilaste juhendamisel ja motiveerimisel ning konstruktivistlikud uskumused. Loodusainete ja teiste ainete õpetajate hinnangute vahel ilmnesid statistiliselt olulised erinevused kõigi nimetatud indeksite puhul (tabel 3).

Tabel 3. TALIS 2013 uuringus osalenud Eesti loodusainete õpetajate (LÕP) ja teiste ainete õpetajate (TÕP) võrdlus TALIS 2013 indeksite keskväärtuste alusel ${ }^{2}$

\begin{tabular}{|c|c|c|c|c|c|c|}
\hline Indeks & Õpetajad & $N$ & Keskväärtus & $\begin{array}{l}\text { Standard- } \\
\text { hälve }\end{array}$ & $t$ & $p$-väärtus \\
\hline \multirow{2}{*}{$\begin{array}{l}\text { Enesetõhusus } \\
\text { õpetamisel }\end{array}$} & LÕP & 2003 & 11,30 & 1,88 & \multirow{2}{*}{4,80} & \multirow{2}{*}{0,000} \\
\hline & TÕP & 5462 & 11,07 & 1,84 & & \\
\hline \multirow{2}{*}{$\begin{array}{l}\text { Enesetõhusus õpilaste } \\
\text { juhendamisel ja } \\
\text { motiveerimisel }\end{array}$} & LÕP & 2003 & 11,86 & 1,58 & \multirow{2}{*}{3,15} & \multirow{2}{*}{0,002} \\
\hline & TÕP & 5462 & 11,73 & 1,51 & & \\
\hline \multirow{2}{*}{$\begin{array}{l}\text { Konstruktivistlikud } \\
\text { uskumused }\end{array}$} & LÕP & 2010 & 12,61 & 1,60 & \multirow{2}{*}{4,66} & \multirow{2}{*}{0,000} \\
\hline & TÕP & 5465 & 12,42 & 1,55 & & \\
\hline
\end{tabular}

Allikas: OECD TALIS 2013 andmebaas, autorite arvutused kaalutud valimiga, $t$-test

2 Kuigi sõltuvalt konkreetsest teoreetilisest alusest võib mitmeid TALIS 2013 uuringus sisaldunud väiteid ja hinnanguid käsitleda nii õpetamispraktika kui ka enesetõhususe alla kuuluvatena, on praeguses analüüsis lähtutud TALIS 2013 korraldajate määratlusest, s.t kui väidet on TALISEe uuringus kasutatud kas enesetõhususe või õpetamispraktika hindamiseks, siis on seda tehtud ka praegusel juhul. 
Tabel 4. TALIS 2013 uuringus osalenud eesti (EÕ), vene (VÕ) ja mõlema õppekeelega (MÕ) koolide loodusainete õpetajate uskumuste ja õpetamispraktika hinnangute võrdlus

\begin{tabular}{|c|c|c|c|c|c|c|}
\hline Väide & $\begin{array}{l}\text { Hinnang } \\
\text { sagedusele }\end{array}$ & $\begin{array}{c}\text { EÕ koolide } \\
\text { õpetajad } \\
N\end{array}$ & $\begin{array}{c}\text { VÕ koolide } \\
\text { õpetajad } \\
N\end{array}$ & $\begin{array}{l}\text { MÕ koolide } \\
\text { õpetajad } \\
N\end{array}$ & $\begin{array}{c}X^{2}- \\
\text { statis- } \\
\text { tik }\end{array}$ & $\begin{array}{c}p- \\
\text { väär- } \\
\text { tus }\end{array}$ \\
\hline \multirow{2}{*}{$\begin{array}{l}\text { Annan erinevaid üles- } \\
\text { andeid õpiraskustega } \\
\text { õpilastele ja/või neile, } \\
\text { kes kiiremini edasi } \\
\text { jõuavad }\end{array}$} & $\begin{array}{l}\text { Harva / } \\
\text { mitte kunagi }\end{array}$ & $\begin{array}{c}337 \\
(58,4 \%)\end{array}$ & $20(34,5 \%)$ & $29(42,0 \%)$ & \multirow{2}{*}{23,127} & \multirow[b]{2}{*}{0,001} \\
\hline & $\begin{array}{l}\text { Sageli / } \\
\text { peaaegu iga tund }\end{array}$ & $\begin{array}{c}240 \\
(41,6 \%)\end{array}$ & $38(65,5 \%)$ & $39(57,4 \%)$ & & \\
\hline \multirow{2}{*}{$\begin{array}{l}\text { Lasen õpilastel } \\
\text { harjutada senikaua, } \\
\text { kuni nad on aru saanud }\end{array}$} & $\begin{array}{l}\text { Harva / } \\
\text { mitte kunagi }\end{array}$ & $\begin{array}{c}207 \\
(35,9 \%)\end{array}$ & $8(13,8 \%)$ & $25(36,8 \%)$ & \multirow{2}{*}{18,536} & \multirow{2}{*}{0,005} \\
\hline & $\begin{array}{l}\text { Sageli / } \\
\text { peaaegu iga tund }\end{array}$ & $\begin{array}{c}369 \\
(64,1 \%)\end{array}$ & $50(86,2 \%)$ & $43(63,2 \%)$ & & \\
\hline \multirow{2}{*}{$\begin{array}{l}\text { Õpilased töötavad } \\
\text { projektidega, mille } \\
\text { teostamiseks kulub } \\
\text { vähemalt nädal }\end{array}$} & $\begin{array}{l}\text { Harva / } \\
\text { mitte kunagi }\end{array}$ & $\begin{array}{c}512 \\
(88,7 \%)\end{array}$ & $47(81,0 \%)$ & $56(82,4 \%)$ & \multirow{2}{*}{13,064} & \multirow{2}{*}{0,042} \\
\hline & $\begin{array}{l}\text { Sageli / } \\
\text { peaaegu iga tund }\end{array}$ & $65(11,3 \%)$ & $11(19,0 \%)$ & $12(17,6 \%)$ & & \\
\hline \multirow[t]{2}{*}{$\begin{array}{l}\text { Aitan õpilastel } \\
\text { kriitiliselt mõelda }\end{array}$} & $\begin{array}{l}\text { Üldse mitte / } \\
\text { mõnel määral }\end{array}$ & $\begin{array}{c}124 \\
(26,7 \%)\end{array}$ & $15(22,1 \%)$ & $22(32,4 \%)$ & \multirow{2}{*}{13,889} & \multirow{2}{*}{0,031} \\
\hline & Vahel/sageli & $\begin{array}{c}341 \\
(73,3 \%)\end{array}$ & $53(77,9 \%)$ & $46(67,6 \%)$ & & \\
\hline \multirow[t]{2}{*}{$\begin{array}{l}\text { Teen kokkuvõtte hiljuti } \\
\text { õpitu sisust }\end{array}$} & $\begin{array}{l}\text { Harva / } \\
\text { mitte kunagi }\end{array}$ & $45(10,8 \%)$ & $14(29,8 \%)$ & $10(20,8 \%)$ & \multirow{2}{*}{25,831} & \multirow{2}{*}{0,000} \\
\hline & $\begin{array}{l}\text { Sageli / } \\
\text { peaaegu iga tund }\end{array}$ & $\begin{array}{c}371 \\
(89,2 \%)\end{array}$ & $33(70,2 \%)$ & $38(79,2 \%)$ & & \\
\hline \multirow{2}{*}{$\begin{array}{l}\text { Õpilased töötavad } \\
\text { väikestes gruppi- } \\
\text { des, et jõuda ühiselt } \\
\text { lahendusteni }\end{array}$} & $\begin{array}{l}\text { Harva / } \\
\text { mitte kunagi }\end{array}$ & $\begin{array}{c}262 \\
(63,1 \%)\end{array}$ & $30(63,8 \%)$ & $25(51,0 \%)$ & \multirow{2}{*}{12,654} & \multirow{2}{*}{0,049} \\
\hline & $\begin{array}{l}\text { Sageli / } \\
\text { peaaegu iga tund }\end{array}$ & $\begin{array}{c}153 \\
(36,9 \%)\end{array}$ & $17(36,2 \%)$ & $24(49,0 \%)$ & & \\
\hline \multirow{2}{*}{$\begin{array}{l}\text { Õpilased kasutavad } \\
\text { klassis või projektide } \\
\text { tegemiseks } \\
\text { IKT-vahendeid }\end{array}$} & $\begin{array}{l}\text { Harva / } \\
\text { mitte kunagi }\end{array}$ & $\begin{array}{c}281 \\
(67,9 \%)\end{array}$ & $26(55,3 \%)$ & $28(58,3 \%)$ & \multirow{2}{*}{16,621} & \multirow{2}{*}{0,011} \\
\hline & $\begin{array}{l}\text { Sageli / } \\
\text { peaaegu iga tund }\end{array}$ & $\begin{array}{c}133 \\
(32,1 \%)\end{array}$ & $21(44,7 \%)$ & $20(41,7 \%)$ & & \\
\hline \multirow{2}{*}{$\begin{array}{l}\text { Annan ülesandeid, } \\
\text { mis näitavad, miks uus } \\
\text { teadmine või oskus on } \\
\text { vajalik igapäevaelu või } \\
\text { töö jaoks }\end{array}$} & $\begin{array}{l}\text { Harva / } \\
\text { mitte kunagi }\end{array}$ & $\begin{array}{c}203 \\
(35,2 \%)\end{array}$ & $13(22,4 \%)$ & $27(39,7 \%)$ & \multirow[b]{2}{*}{20,419} & \multirow[b]{2}{*}{0,002} \\
\hline & $\begin{array}{l}\text { Sageli / } \\
\text { peaaegu iga tund }\end{array}$ & $\begin{array}{c}373 \\
(64,8 \%)\end{array}$ & $21(77,6 \%)$ & $20(60,3 \%)$ & & \\
\hline
\end{tabular}

Allikas: OECD TALIS 2013 andmebaas, autorite arvutused, $x^{2}$-test 
Kuna TALIS 2008 ja TALIS 2013 uuringus kattusid õpetajate uskumuste ning õpetamispraktika koondtunnused väikeses osas, kasutati $\chi^{2}$-testi ning võrreldi TALIS 2013 eesti, vene ja mõlema õppekeelega koolides õpetavate loodusainete õpetajate enesetõhususe ja konstruktivistlike uskumuste hinnanguid üksikküsimuste kaupa. Statistiliselt olulised erinevused ilmnesid üheksa küsimuse puhul (tabel 4).

Vene õppekeelega koolide õpetajate enesetõhususe hinnangud õpilaste motiveerimisel ja juhendamisel olid enamasti kõrgemad. Eesti õppekeelega koolide õpetajate hinnangud olid kõrgemad ainult väite Teen kokkuvõtte hiljuti õpitu sisust korral $(p<0,001)$ (tabel 4).

TALIS 2013 uuringus osalenud eri õppekeelega koolide loodusainete õpetajate uskumuste ja õpetamispraktikaga seotud vastuseid uuriti ANOVA abil. Kooli õppekeele alusel eristus kolm gruppi. Eri õppekeelega koolide loodusainete õpetajate hinnangute vahel ilmnesid statistiliselt olulised erinevused kõigi uuritavate indeksite puhul (tabel 5).

Tabel 5. TALIS 2013 uuringus osalenud eesti, vene ja mõlema õppekeelega koolide loodusainete õpetajate enesetõhususe ja uskumuste hinnangute võrdlus TALIS 2013 indeksite keskväärtuste alusel

\begin{tabular}{|c|c|c|c|c|c|c|}
\hline Indeks & $\begin{array}{l}\text { Kooli } \\
\text { õppekeel }\end{array}$ & $N$ & $\begin{array}{c}\text { Keskväär- } \\
\text { tus }\end{array}$ & $\begin{array}{l}\text { Standard- } \\
\text { hälve }\end{array}$ & $F$ & $p$-väärtus \\
\hline \multirow{3}{*}{$\begin{array}{l}\text { Enesetõhusus õpeta- } \\
\text { misel }\end{array}$} & Eesti & 1510 & 11,22 & 1,88 & \multirow{3}{*}{6,13} & \multirow{3}{*}{0,002} \\
\hline & Vene & 224 & 11,43 & 1,68 & & \\
\hline & Eesti/vene & 269 & 11,63 & 1,91 & & \\
\hline \multirow{3}{*}{$\begin{array}{l}\text { Enesetõhusus õpi- } \\
\text { laste juhendamisel ja } \\
\text { motiveerimisel }\end{array}$} & Eesti & 1510 & 11,80 & 1,55 & \multirow{3}{*}{5,30} & \multirow{3}{*}{0,005} \\
\hline & Vene & 224 & 11,89 & 1,54 & & \\
\hline & Eesti/vene & 269 & 12,14 & 1,74 & & \\
\hline \multirow{3}{*}{$\begin{array}{l}\text { Konstruktivistlikud } \\
\text { uskumused }\end{array}$} & Eesti & 1517 & 12,65 & 1,60 & \multirow{3}{*}{5,45} & \multirow{3}{*}{0,004} \\
\hline & Vene & 224 & 12,28 & 1,62 & & \\
\hline & Eesti/vene & 269 & 12,61 & 1,55 & & \\
\hline
\end{tabular}

Allikas: OECD TALIS 2013 andmebaas, autorite arvutused kaalutud valimiga, ANOVA

Kõige madalamad hinnangud indeksites enesetõhusus õpetamisel ning enesetõhusus ópilaste juhendamisel ja motiveerimisel olid eesti õppekeelega koolide õpetajatel. Kõige kõrgemate enesetõhususe hinnangute poolest paistsid silma mõlema õppekeelega koolides töötavad õpetajad. (Samas olid kõige kõrgemad konstruktivistlike uskumuste hinnangud eesti õppe- 
keelega koolide loodusainete õpetajatel). Post hoc-test näitas indeksites enesetõhusus õpetamisel ning enesetõhusus ópilaste juhendamisel ja motiveerimisel statistiliselt olulist erinevust eesti ja mõlema õppekeelega koolide õpetajate hinnangute vahel $(p=0,001)$. Eesti õppekeelega koolide õpetajad hindasid oma enesetõhusust õpilaste juhendamisel ja motiveerimisel kõige madalamalt $(p=0,001)$. Ka konstruktivistlike uskumuste puhul ilmnes statistiliselt oluline erinevus eesti ja vene õppekeelega koolide õpetajate hinnangute vahel $(p=0,001)$. Eesti õppekeelega koolide õpetajate uskumused olid konstruktivistlikumad.

Järgmises etapis analüüsiti uuringu TALIS 2013 loodusainete ja teiste ainete õpetajate ning eesti, vene ja mõlema õppekeelega koolides õpetavate loodusainete õpetajate hinnanguid nende õpetamispraktika kohta. Erinevalt TALIS 2008 kolmest õpetamispraktika indeksist kirjeldati TALIS 2013 uuringus õpetamispraktikat passiivse või aktiveerivana ning seetõttu võrreldi õpetajate hinnanguid üksikküsimuste kaupa. Uurimistulemustest selgus, et TALIS 2013 uuringus puudusid aktiveerivat praktikat iseloomustava väite puhul loodusainete ja teiste õpetajate õpetamispraktika hinnangute vahel statistiliselt olulised erinevused. Eesti, vene ja mõlema õppekeelega koolide õpetajate õpetamispraktika hinnangute võrdlemisel ilmnesid statistiliselt olulised erinevused kahe küsimuse puhul: a) Õpilased töötavad projektidega, mille teostamiseks kulub vähemalt nädal; b) Õpilased kasutavad klassis või projektide tegemiseks IKT-vahendeid (tabel 4). Vene õppekeelega koolide loodusainete õpetajad väitsid korraldavat selliseid tegevusi sagedamini.

\section{Arutelu}

\section{Õpetajate uskumused}

Kõige tulemuslikumaks peetakse tänapäeval konstruktivistlikku õppimist ja õpetamist (Furtak et al., 2012). Samamoodi nagu TALIS 2008 ja TALIS 2013 võrdlusanalüüsidest (OECD, 2010b, 2014a), ilmnes ka praegusel juhul, et võrreldes teiste ainete õpetajatega on loodusainete õpetajate uskumused konstruktivistlikumad. Seega leidis artiklis esitatud esimene hüpotees loodusainete õpetajate konstruktivistlike uskumuste kohta kinnitust. See on iseenesest väga lootustandev, ehkki, nagu ka Kikas (2013) on märkinud, ei saa eeldada, et õpetajate konstruktivistlike uskumustega kaasneks õpilaskesksete tegevuste ja uurimusliku õppe suurem rakendamine. Seda kahtlust toetab ka 2011. aasta riiklike õppekavade rakendamise uuring, mis näitas, et Eesti loodusainete õpetajad tähtsustasid õppekavade konstruktivistlikku 
õpikäsitust ning õppekavasse kirjutatud praktilisi tegevusi ja uurimuslikku õpet, ent väitsid samas, et ei kavatse muuta oma õpetamispraktikat (Henno \& Granström, 2012).

Analüüs võimaldab väita, et loodusainete õpetajate uskumused ei ole vaadeldud ajavahemiku jooksul oluliselt muutunud. Mõlemas uuringus olid need uskumused teiste ainete õpetajate omadest konstruktivistlikumad. Erandiks olid sellised väited nagu kõige paremini õpivad õpilased siis, kui leiavad iseseisvalt probleemidele lahendusi, ópilastel peaks võimaldama mõelda ise lahenduste üle või mõtlemine ja järelduste tegemine on tähtsam kui ainekava konkreetne sisu. Lisaks ilmnes analüüsist, et varasema uuringuga võrreldes olid loodusainete õpetajate enesetõhususe hinnangud teiste õpetajate hinnangutest kõrgemad.

Loodusainete seisukohalt oli analüüsi tulemustes eriti positiivne, et loodusainete õpetajad väitsid teistest Eesti aineõpetajatest sagedamini, et nende roll on toetada õpilaste uurimistegevust. Samas ilmnes uuringu TALIS 2013 rahvusvahelisest raportist, et tervikuna järjestusid Eesti õpetajad selle väitega nõustumise poolest osalenud riikide hulgas keskmisest allapoole. Samuti oli see nii väitega kõige paremini ópivad õpilased siis, kui leiavad iseseisvalt probleemidele lahendusi (OECD, 2014a).

\section{Enesetõhusus}

Õpetaja professionaalsus on seotud enesetõhususega (Klassen et al., 2011; Ross, 1998; Ross \& Bruce, 2007). TALIS 2008 ja TALIS 2013 uuringu järgi olid Eesti õpetajate enesetõhususe hinnangud rahvusvahelises võrdluses ühed madalaimad (OECD, 2014a). TALIS 2008 põhjal tehtud Eesti-sisene võrdlus teiste aineõpetajatega näitas, et loodusainete õpetajate enesetõhususe hinnangud olid veelgi madalamad. Seevastu TALIS 2013 andmetel põhinevast analüüsist ilmnes, et võrreldes teiste õpetajatega olid loodusainete õpetajate enesetõhususe hinnangud kõrgemad: õpetajad hindasid end edukamaks õpilaste juhendamisel ja motiveerimisel. Seega ei leidnud kinnitust hüpotees, et loodusainete õpetajate enesetõhususe hinnangud on teiste õpetajate hinnangutega samaväärsed. Ilmnes, et võrreldes teiste õpetajatega on loodusainete õpetajate enesetõhususe hinnangud paranenud. See võib soodustada kognitiivselt aktiveeriva õpetamispraktika rakendamist.

Loodusainete õpetajate enesetõhususe hinnangute paranemine teiste ainete õpetajate omadega võrreldes on iseenesest positiivne. Samas oli õpilaste huvi äratamise seisukohalt kahetsusväärne, et võrreldes teiste õpetajatega väitsid loodusainete õpetajad harvemini motiveerivat õpilasi, kel oli vähene huvi aine vastu. Eesti õpilaste vähesele huvile loodusainetega seotud 
karjäärivalikute vastu on osutanud teisedki uurijad (Kollo, 2016; Lond, 2010; Soobard \& Rannikmäe, 2014).

Varasemad TALIS 2008 sekundaaranalüüsid on näidanud, et eesti ja vene õppekeelega koolide õpetajate enesetõhususe hinnangud ei erine statistiliselt olulisel määral (Henno, 2015). Seevastu praeguse uurimuse raames tehtud TALIS 2013 analüüsist ilmnes, et eesti õppekeelega koolide loodusainete õpetajad hindavad oma enesetõhusust õpilaste õpetamisel, juhendamisel ja motiveerimisel vene õppekeelega koolide loodusainete õpetajatest madalamalt (ehkki nende uskumused on konstruktivistlikumad). Artiklis püstitatud kolmas hüpotees, et eesti ja vene õppekeelega koolide loodusainete õpetajate uskumused ja enesetõhususe hinnangud on sarnased, ei leidnud kinnitust.

\section{Õpetamispraktika}

Hüpotees, et võrreldes teiste õpetajatega pööravad loodusainete õpetajad suuremat tähelepanu õpilasi aktiveeriva praktika rakendamisele, ei leidnud kinnitust. Sekundaaranalüüsid näitasid, et võrreldes teiste ainete õpetajatega väidavad Eesti loodusainete õpetajad TALIS 2008 uuringus harvemini, et nad rakendavad õpilastele orienteeritud ja kõrgema tasandi mõtlemisoskusi kujundavat õpetamispraktikat. Ka TALIS 2008 uuringu raport näitas, et võrreldes teiste õpetajatega rakendavad loodusainete õpetajad enamasti struktureeritud õpetamispraktikat ning vähem nii õpilastele orienteeritud kui ka kõrgema tasandi mõtlemisoskusi kujundavat õpetamispraktikat (OECD, 2010b).

Kui TALIS 2013 lõppraportist ilmnes, et loodusainete õpetajad rakendavad võrreldes teiste ainete õpetajatega vähem aktiveerivat õpetamispraktikat (OECD, 2014a), siis seda tulemust siinne analüüs otseselt siiski ei kinnita. Samas ei ilmnenud Eesti andmete põhjal mitte ühegi aktiveeriva praktika väite puhul loodusainete ja teiste õpetajate hinnangute vahel statistiliselt olulist erinevust. Erinevus ilmnes aga eesti ja vene õppekeelega koolide loodusainete õpetajate hinnangute vahel. Vene õppekeelega koolide loodusainete õpetajate vastused olid ka vastuolulisemad. Nad väitsid sagedamini, et korraldavad pikaajalisi projekte ja et nende õpilased kasutavad projektides IKT-vahendeid. Samuti väitsid nad sagedamini, et aitavad õpilastel kriitiliselt mõelda, annavad ülesandeid, mis näitavad, miks teadmine või oskus on vajalik igapäevaelu jaoks, ning annavad erinevaid ülesandeid õpiraskustega õpilastele. Need vastused viitaksid õpilasele orienteeritud õpetamispraktika sagedamale kasutamisele vene õppekeelega koolides. Samas väitsid vene õppekeelega koolide õpetajad oluliselt sagedamini, et lasevad ópilastel praktiseerida sarnaseid ülesandeid, kuni 
kõik õpilased on õpetatavast aru saanud. Vene õppekeelega koolide õpetajakesksetele õpetamisarusaamadele ja -meetoditele koos õpilaste nõrgemate metakognitiivsete õpioskuste kujundamisega on osutatud ka teistes Eesti uurimustes (Säälik, 2012).

Kui vene õppekeelega koolide loodusainete õpetajad kasutavad eesti õppekeelega koolide õpetajatega võrreldes sagedamini õpilasele orienteeritud ja õpilaste kõrgema tasandi mõtlemisoskusi kujundavaid õpetamisviise, peaks vene õppekeelega koolide õpilaste sooritus loodusteadustes olema PISA uuringutes eesti õppekeelega koolide õpilaste omast parem ning tippsooritajate osakaal suurem. Tegelikult on vene õppekeelega koolide õpilaste sooritused loodusainetes olnud nõrgemad kõigis PISA uuringutes (Henno, 2016).

Positiivseks leiuks oli, et loodusainete õpetajad väitsid sagedamini kui teised õpetajad, et aitavad õpilastel kriitiliselt mõelda. Samas ei ilmnenud vaadeldud õpetajagruppide hinnangutes statistiliselt olulisi erinevusi õpilaste eneseusu kujundamise küsimuses. Ilmselt ei olnud see õpetajatele kõige tähtsam. Rahvusvahelisest võrdlusest ilmnes hoopis, et Eesti õpetajad väitsid teiste riikide õpetajatest tunduvalt harvemini, et aitavad õpilastel kriitiliselt mõelda ja kujundavad neis usku koolis hästi hakkamasaamisse (OECD, 2014a).

Nii praegune analüüs kui ka varasemad uuringud näitavad loodusainete õpetajate uskumuste ja õpetamispraktika hinnangute vahelist vastuolu. Kuna uurimuslik õpe parandab õpilaste kognitiivseid tulemusi ja kriitilist mõtlemist (Blanchard et al., 2010; Furtak et al., 2012; Hattie, 2009), siis võibki Eesti tippsooritajate vähene osakaal PISA uuringutes olla seotud traditsioonilise õpetamispraktika domineerimisega ja sellega, et konstruktivistlik käsitlus oma tegelikus tähenduses ei ole reaalselt loodusainete tundi jõudnud. Selleks, et tippsooritajate osakaal suureneks ning õpilaste mõtlemis- ja probleemilahendusoskused reaalselt paraneksid, peaks loodusainete õpetajate õpetamispraktika olema märksa õpilaskesksem. Kui õpetajad sõnades toetavad loodusteaduslikku uurimuslikku õpet, siis peaks praeguses uuringus leitu väljenduma ka Eesti õpetajate igapäevases õpetamispraktikas ja uurimusliku õppe sagedamas rakendamises. Eesti õpilaste PISA 2016 tagasisidest ilmnes samuti, et Eesti koolides rakendatakse praktilisi tegevusi ja uurimuslikku õpet loodusainete tundides tunduvalt harvemini, kui nähtub OECD keskmisest (OECD, 2016). Ka teised Eesti uurijad on tõdenud, et loodusainete õpetamise praktika muutused on väga aeglased juurduma (Laius et al., 2009; Laius \& Rannikmäe, 2011; Laius et al., 2008). Übius jt (2014) tõestasid samuti, et Eesti õpetajate konstruktivistlikud uskumused on aktiveeriva praktikaga suhteliselt nõrgalt seotud. 
Kuigi riikliku õppekava eesmärgid eeldavad õpilastelt kognitiivselt aktiveeriva õpetamispraktika rakendamist, näitas praegune analüüs, et loodusainete tundides ei pöörata jätkuvalt piisavat tähelepanu ópilaste aktiveerimisele ja motiveerimisele ning uurimuslikule õppele. Samas loovad eesti õppekeelega koolide loodusainete õpetajate konstruktivistlikud uskumused ja kõrgemad enesetõhususe hinnangud paremad eeldused sellise praktika rakendamiseks.

\section{Kokkuvõte}

Uurimistöö eesmärk oli välja selgitada, kas ja kuidas on Eesti loodusainete õpetajate uskumused, õpetamispraktika ning enesetõhusus viimastel aastatel muutunud. Uurimusest ilmnes, et võrreldes teiste aineõpetajatega olid loodusainete õpetajate uskumused nii TALIS 2008 kui ka TALIS 2013 uuringus konstruktivistlikumad. TALIS 2008 uuringuga võrreldes olid loodusainete õpetajate enesetõhususe hinnangud TALIS 2013 uuringus paranenud. Kui TALIS 2008 analüüsidest selgus, et eesti ja vene õppekeelega koolide loodusainete õpetajate uskumused ning enesetõhususe hinnangud statistiliselt oluliselt ei erinenud, siis praegune analüüs näitas, et vene õppekeelega koolide loodusainete õpetajate uskumused olid varasemast vähem konstruktivistlikud. Seevastu eesti õppekeelega koolide loodusainete õpetajate hulgas olid madalamate enesetõhususe hinnangutega õpetajaid.

Tehtud analüüs kinnitas eelnevates uuringutes ilmnenud tõsiasja, et vene õppekeelega koolide loodusainete õpetajate hinnangud on positiivsemad ja vastuolulisemad kui eesti óppekeelega koolide õpetajate omad. Vene õppekeelega koolide õpetajad väitsid eesti õppekeelega koolide õpetajatest sagedamini, et aitavad õpilastel kriitiliselt mõelda, kuid nentisid samas, et lasevad õpilastel harjutada senikaua, kuni nad on aru saanud.

TALIS 2008 uuringus väitsid loodusainete õpetajad teistest õpetajatest sagedamini, et rakendavad struktureeritud õpetamispraktikat, seevastu õpilastele orienteeritud ja kõrgema tasandi mõtlemisoskusi kujundavat praktikat kasutavad nad harvem. Kinnitust ei leidnud hüpotees, et loodusainete õpetajate väitel pööratakse põhikooli III astme loodusainete tundides suuremat tähelepanu õpilaste aktiveerimisele. TALIS 2013 uuringu põhjal ei ilmnenud statistiliselt olulisi erinevusi loodusainete ja teiste ainete õpetajate aktiveerivat praktikat kirjeldavate hinnangute vahel. Seega ei ole jätkuvalt alust eeldada, et loodusainete õpetajad rakendavad oluliselt enam õpilasi aktiveerivat praktikat ja kujundavad tõhusamalt õpilaste kõrgema tasandi mõtlemisoskusi. 
Tuginedes TALIS 2008 ja TALIS 2013 uuringu sekundaaranalüüsidele, saab väita, et väga suuri muutusi Eesti loodusainete õpetajate uskumustes ja õpetamispraktikas ei ole toimunud. Kuigi tulemus, et loodusainete õpetajate uskumused on tugevalt konstruktivistlikud, on lootustandev, näitas TALIS 2013 õpetajate õpetamispraktika hinnangute analüüs, et jätkuvalt ei tähtsusta loodusainete õpetajad õpilaste motiveerimist ega rakenda piisavalt õpilasi aktiveerivat õpetamispraktikat.

\section{Kasutatud kirjandus}

Bandura, A. (1997). Self-efficacy: The exercise of control. New York: W. H. Freeman and Company.

Baumert, J., Kunter, M., Blum, W., Brunner, M., Voss, T., Jordan, A., ... Tsai, Y.-M. (2010). Teachers' mathematical knowledge, cognitive activation in the classroom, and student progress. American Educational Research Journal, 47(1), 133-180. https://doi.org/10.3102/0002831209345157

Blanchard, S., Freiman, V., \& Lirrete-Pitre, N. (2010). Strategies used by elementary schoolchildren solving robotics-based complex tasks: Innovative potential of technology. Procedia - Social and Behavioral Sciences, 2(2), 2851-2857. https://doi.org/10.1016/j.sbspro.2010.03.427

Bloom, B. S. (1976). Human characteristics and school learning. New York: McGraw Hill.

Brophy, J. E., \& Good, T. L. (1986). Teacher behavior and student achievement. In M. C. Wittrock (Ed.), Handbook of research on teaching (3rd ed., pp. 328-375). New York: Maxmillan.

Bruner, J. S. (1960). The process of education. Cambridge: Harvard University Press.

Bruner, J. S. (1961). The act of discovery. Harvard Educational Review, 31(1), 21-32.

Bybee, R. W. (2006). Scientific inquiry and science teaching. In L. B. Flick \& N. G. Lederman (Eds.), Scientific inquiry and nature of science: Implications for teaching, learning and teacher education (pp. 1-14). Dordrecht: Springer.

Creemers, B. P. M., \& Kyriakides, L. (2008). The dynamics of educational effectiveness: A contribution to policy, practice and theory in contemporary schools. New York: Routledge.

Duffy, T. M., \& Jonassen, D. H. (1992). Constructivism and the technology of instruction: A conversation. Hillsdale: Lawrence Erlbaum Associates.

Furtak, E. M., Seidel, T., Iverson, H., \& Briggs, D. C. (2012). Experimental and quasiexperimental studies of inquiry-based science teaching: A meta-analysis. Review of Educational Research, 82(3), 300-329. https://doi.org/10.3102/0034654312457206

Goodson, I., Moore, S., \& Hargreaves, A. (2006). Teacher nostalgia and the sustainability of reform: The generation and degeneration of teachers' missions, memory, and meaning. Educational Administration Quarterly, 42(1), 42-61.

https://doi.org/10.1177/0013161X05278180 
Gümnaasiumi riiklik õppekava (2011). Riigi Teataja I, 29.08.2014, 21. Külastatud aadressil https://www.riigiteataja.ee/akt/129082014021.

Hattie, J. A. C. (2009). Visible learning: A synthesis of 800+ meta-analyses on achievement. Abingdon: Routledge.

Henno, I. (2010). Mida on loodusteaduste õpetajatel õppida rahvusvahelisest võrdlusuuringust PISA 2006? I. Henno (koost.), Rahvusvaheliste võrdlusuuringute TIMSS 2003 ja PISA 2006 óppetunnid (lk 19-67). Tallinn: SA Archimedes.

Henno, I. (2015). Loodusteaduste óppimisest ja õpetamisest Eesti koolides rahvusvaheliste võrdlusuuringute taustal (doktoritöö). Tallinn: Tallinna Ülikool.

Henno, I. (2016). Loodusteadused. G. Tire, I. Henno jt (toim.), PISA 2015 Eesti tulemused: Eesti 15-aastaste õpilaste teadmised ja oskused loodusteadustes, funktsionaalses lugemises ja matemaatikas (lk 18-54). Tallinn: SA Innove.

Henno, I., \& Granström, S. (2012). Ülevaade aineõpetajate ja koolijuhtide veebiküsitlusest „Uutest riiklikest óppekavadest lähtuv kooli óppekavade arendus ja rakendamine“. Tallinn: Haridus- ja Teadusministeerium.

Hofstein, A., \& Lunetta, V. N. (2004). The laboratory in science education: Foundations for the twenty-first century. Science Education, 88(1), 28-54. https://doi.org/10.1002/sce.10106

Holbrook, J. (2008). Paradigm shifts in science education. In J. Holbrook, M. Rannikmäe, P. Reiska, \& P. Ilsey (Eds.), The need for a paradigm shift in science education for post-Soviet societies: Research and practice (pp. 7-24). Frankfurt am Main: Peter Lang.

Kikas, E. (2013). Õpilasekesksest õppimisest ja õpetamisest. M. Kass (koost.), Seestpoolt suurem Eesti. Haridus ja haritus. Metsaülikool Eestis 2011-2012 (lk 70-83). Tartu: SE \& JS.

Kirschner, P. A., Sweller, J., \& Clark, R. E. (2006). Why minimal guidance during instruction does not work: An analysis of the failure of constructivist, discovery, problem-based, experiential, and inquiry-based teaching. Educational Psychologist, 41(2), 75-86. https://doi.org/10.1207/s15326985ep4102_1

Klassen, R. M., Tze, V. M. C., Betts, S. M., \& Gordon, K. A. (2011). Teacher efficacy research 1998-2009: Signs of progress or unfulfilled promise? Educational Psychology Review, 23(1), 21-43. https://doi.org/10.1007/s10648-010-9141-8

Klieme, E., Lipowsky, F., Rakoczy, K., \& Ratzka, N. (2006). Qualitätsdimensionen und wirksamkeit von mathematikunterricht: Theoretische grundlagen und ausgewählte ergebnisse des projekts „Pythagoras“. In M. Prenzel \& L. Allolio-Näcke (Eds.), Untersuchungen zur Bildungsqualität von Schule, Abschlussbericht des DFGSchwerpunktprogramms (pp. 128-146). Münster: Waxmann.

Kobarg, M., Prenzel, M., Seidel, T., Walker, M., McCrae, B., Cresswell, J., \& Wittwer, J. (2011). An international comparison of science teaching and learning: Further results from PISA 2006. Münster: Waxmann.

Kollo, L. (2016). Loodusainete õpetajate uskumused ja õpetamispraktikad TALIS 2013s ning gümnasistide tagasiside loodusainete õpetamisele põhikoolis (magistritöö). Tallinn: Tallinna Ülikool.

Kunter, M., Klusmann, U., Baumert, J., Richter, D., Voss, T., \& Hachfeld, A. (2013). Professional competence of teachers: Effects on instructional quality and student development. Journal of Educational Psychology, 105(3), 805-820. 
Laius, A., Kask, K., \& Rannikmäe, M. (2009). Comparing outcomes from two case studies on chemistry teachers' readiness to change. Chemistry Education Research and Practice, 10(2), 142-153. https://doi.org/10.1039/B908251B

Laius, A., \& Rannikmäe, M. (2011). Impact on student change in scientific creativity and socio-scientific reasoning skills from teacher collaboration and gains from professional in-service. Journal of Baltic Science Education, 10(2), 127-137.

Laius, A., Rannikmäe, M., \& Yager, R. (2008). A paradigm shift for teachers: Enhancing students' creativity and reasoning skills. In J. Holbrook, M. Rannikmäe, P. Reiska, \& P. Ilsley (Eds.), The need for a paradigm shift in science education for post-Soviet societies: Research and practice (pp. 67-85). Frankfurt am Main: Peter Lang.

Lond, M. (2010). Tallinna gümnasistide karjääriteadlikkus ja instrumentaalne ning tulevikule suunatud huvi oppida loodusteadusi (magistritöö). Tallinn: Tallinna Ülikool.

Loogma, K., Ruus, V-R., Talts, L., \& Poom-Valickis, K. (2009). Õpetaja professionaalsus ning tõhusama õpetamis- ja õppimiskeskkonna loomine. OECD rahvusvahelise ópetamise ja õppimise uuringu TALIS tulemused. Tallinn: Tallinna Ülikooli haridusuuringute keskus. Külastatud aadressil https://www.hm.ee/sites/default/files/talis2008.pdf.

Mayer, R. E. (2004). Should there be a three-strikes rule against pure discovery learning? The case for guided methods of instruction. American Psychologist, 59(1), 14-19. https://doi.org/10.1037/0003-066X.59.1.14

Mayer, R. E. (2009). Constructivism as a theory of learning versus constructivism as a prescription for instruction. In S. Tobias \& T. M. Duffy (Eds.), Constructivist instruction: Success or failure? (pp. 184-200). New York: Routledge.

National Research Council (1996). National science education standards. Washington: National Academy Press.

OECD (2007). PISA ${ }^{T M}$ 2006. Science competencies for tomorrow's world (Vol. 1 Analysis). Paris: OECD.

OECD (2009). PISA data analysis manual: SPSS second edition. Paris: OECD.

OECD (2010a). PISA 2009 results: What students know and can do - Student performance in reading, mathematics and science (Vol. 1). Paris: OECD. Retrieved from http://www.oecd.org/pisa/pisaproducts/48852548.pdf.

OECD (2010b). Teaching and Learning International Survey - TALIS 2008. Technical report. Paris: OECD. Retrieved from https://www.oecd.org/edu/school/44978960.pdf.

OECD (2013a). PISA 2012 results: What students know and can do - Student performance in reading, mathematics and science (Vol. 1). Paris: OECD. http://www.cafepedagogique.net/lexpresso/Documents/docsjoints/pztome1.pdf.

OECD (2014a). TALIS 2013 results: An international perspective on teaching and learning. Paris: OECD.

OECD (2014b). TALIS 2013 technical report. Paris: OECD. Retrieved from https://www.oecd.org/edu/school/TALIS-technical-report-2013.pdf.

OECD (2016). PISA 2015 results: Excellence and equity in education (Vol. 1). Paris: OECD.

Peterson, P. L., Fennema, E., Carpenter, T. P., \& Loef, M. (1989). Teachers' pedagogical content beliefs in mathematics. Cognition and Instruction, 6(1), 1-40. https://doi.org/10.1207/s1532690xci0601_1 
Piaget, J. (1952). The origins of intelligence in children. New York: International University Press.

Põhikooli riiklik õppekava (2011). Riigi Teataja I, 29.08.2014, 20. Külastatud aadressil https://www.riigiteataja.ee/akt/129082014020.

Rannikmäe, M. (2008). A paradigm shift for the system: Enhancing teacher ownership and professional development. In J. Holbrook, M. Rannikmäe, P. Reiska, \& P. Ilsey (Eds.), The need for a paradigm shift in science education for post-Soviet societies: Research and practice (pp. 199-215). Frankfurt am Main: Peter Lang.

Ross, J. A. (1998). The antecedents and consequences of teacher efficacy. In J. Brophy (Ed.), Advances in research on teaching (Vol. 7, pp. 49-74). Greenwich: JAI Press.

Ross, J. A., \& Bruce, C. (2007). Self-assessment and professional growth: The case of a grade 8 mathematics teacher. Teaching and Teacher Education, 23(2), 146-159. https://doi.org/10.1016/j.tate.2006.04.035

Ruus, V-R., Veisson, M., Leino, M., Ots, L., Pallas, L., Sarv, E.-S., \& Veisson, A. (2007). Ôpilaste edukus, toimetulek ja heaolu koolis. M. Veisson \& V-R. Ruus (koost.), Eesti kool 21. sajandi algul: kool kui arengukeskkond ja ópilaste toimetulek (lk 17-58). Tallinn: Tallinna Ülikooli Kirjastus.

Seidel, T., \& Scheerens, J. (2005). Towards a research review and meta-analysis on teaching and learning: Preliminary results and proposed next steps. Paper for the joint Network A and C Task Force on Teaching Effectiveness of OECD INES, Reykjavik, October 8-9, 2005.

Soobard, R., \& Rannikmäe, M. (2014). Upper secondary students' self-perceptions of both their competence in problem solving, decision making and reasoning within science subjects and their future careers. Journal of Baltic Science Education, 13(4), 544-558.

Säälik, Ü. (2012). Millised on vene ja eesti õppekeelega koolides õpetaja-õpilase suhted, distsipliin, hindamine, õpi- ning õpetamismeetodid? J. Mikk, M. Kitsing, O. Must, Ü. Säälik, \& K. Täht (koost.), Eesti PISA 2009 kontekstis: tugevused ja probleemid. Programmi Eduko uuringutoetuse kasutamise lepingu aruanne (lk 72-81). Tartu: Haridus- ja Teadusministeerium. Külastatud aadressil https://www.hm.ee/sites/default/files/eesti_pisa_2009_kontekstis.pdf.

Vaino, K. (2013). A case study approach to effect change of chemistry teacher beliefs for enhancing students' scientific literacy (Doctoral dissertation). Tartu: University of Tartu Press.

Vieluf, S., Kaplan, D., Klieme, E., \& Bayer, S. (2012). Teaching practices and pedagogical innovations: Evidence from TALIS. OECD Publishing. Retrieved from https://www.oecd.org/edu/school/TalisCeri\%202012\%20(tppi)--Ebook.pdf.

Võgotski, L. S. (1978). Mind in society: The development of higher psychological processes. Cambridge: Harvard University Press.

Übius, Ü., Kall, K., Loogma, K., \& Ümarik, M. (2014). Rahvusvaheline vaade õpetamisele ja óppimisele. OECD rahvusvahelise õpetamise ja õppimise uuringu TALIS 2013 tulemused. Tallinn: SA Innove. Külastatud aadressil https://www.hm.ee/sites/default/files/talis2013_eesti_raport.pdf. 


\title{
Estonian science teachers' pedagogical beliefs, teaching practices and self-efficacy based on the results of the TALIS 2008 and 2013 reports
}

\author{
Imbi Henno ${ }^{\mathrm{a} 1}$, Liina Kollo ${ }^{\mathrm{a}}$, Rain Mikser ${ }^{\mathrm{b}}$ \\ a School of Natural Sciences and Health, Tallinn University \\ ${ }^{b}$ School of Educational Sciences, Tallinn University
}

\section{Summary}

\section{Introduction}

Estonia has recognised that educational analyses constitute an important basis for national education policies, and has participated in the international comparative OECD studies PISA in 2006, 2009 and 2012, and TALIS in 2008 and 2013. Estonian students have performed remarkably well in international comparative studies that have assessed students' learning outcomes in science (OECD, 2007, 2010a, 2013a, 2016). However, the studies also revealed that although the Estonian educational system has been successful in enhancing students' achievements in general, statistically significant differences exist in science competences between the achievements of schools where children are taught either in Estonian or Russian. PISA describes student performance by seven levels of proficiency in science (OECD, 2016). In Estonian language instruction schools, there are a small number of 15-year-olds who are highly proficient (top performers) in science subjects, reaching level 5 or 6 , and even fewer students, in schools where Russian is the language of instruction who reach to these levels.

The secondary analysis of PISA 2006, 2012 and TALIS results has revealed that students' performance and engagement construct differences are connected with the instructional approach given at classroom level. In both Estonian and Russian language schools traditional teaching methods dominate and are rarely applied to inquiry teaching and learning (Henno, 2015).

The method of teaching science can affect the students' performance, beliefs and interest in the subject (Kobarg et al., 2011; Seidel \& Scheerens, 2005). Even if there is no single "best" way of teaching, students need teachers who have different instructional practices (Vieluf et al., 2012).

School of Natural Sciences and Health, Tallinn University, Narva mnt 29, 10120 Tallinn, Estonia; ihenno@tlu.ee 
The teaching strategies used by teachers can be grouped into different approaches: teacher-directed instruction, student-entered instruction, inquiry-based instruction etc. (OECD, 2016). The goal of teacher-directed science instruction is to provide a well-structured, clear and informative lesson which usually includes teachers' explanations and students' questions (Brophy \& Good, 1986). The inquiry-based instruction deals with engaging students in experimentation and hands-on activities, and challenges and encourages them to develop a conceptual understanding (Bybee, 2006). Previous studies show that inquiry-based instruction can improve the students' learning, their attitudes towards science, and critical thinking (Blanchard et al., 2010; Furtak et al., 2012; Hattie, 2009).

The Estonian Lifelong Learning Strategy 2020 approved by the Estonian Government in 2014 includes five strategic goals. The first goal is to change the approach of students to learning and implement an approach that supports their individual and social development, learning skills and creativity. It is important to highlight that the new Estonian National Curriculum for Basic School and Estonian National for Upper-Secondary Schools (2011) was developed as a competency-based curriculum with the aim of enhancing students' scientific and technological literacy, and implement more inquiry-based teaching and learning.

Estonian researchers have studied Estonian science teachers' beliefs about teaching and classroom teaching practices. Changes to classroom practices have been very slow, but changes are shown to be possible (Laius et al., 2009; Laius \& Rannikmäe, 2011; Laius et al., 2008). In recent years the need for change in the Estonian education policy and national curriculum has been clearly expressed, and changes in the training of science teachers' have taken place. However, it is important to understand the teachers' beliefs, practices and attitudes, because these are related to the implementation of science-related activities at school. The science teacher needs to decide which strategies to use in the classroom, and how much time will be devoted to explanations or hands-on activities.

The aim of this study was to determine whether the beliefs of science teachers and teaching practice have been changed in recent years. The aim was to give a picture of the situation of science teaching and science teachers' beliefs based on TALIS 2013, compared to the TALIS 2008 results. The OECD PISA and TALIS studies compile the international comparative analyses and reports and never analyse all the data collected. An intercountry secondary analyses has to be compiled by the researchers' interested in the different topics. 
Answers were sought to the questions: "what were the natural science and other subjects' teachers and the Estonian and Russian-language instruction schools' science teachers' pedagogical beliefs and feedback to teaching practices in TALIS 2013?" and "what changes have taken place in science teachers' beliefs and teaching practices between TALIS 2008 and 2013?”

The research hypotheses were:

- in comparison with the other subject teachers, the science teachers strongly support constructivist beliefs, but they have the same level of self-efficacy;

- in comparison with the other subject teachers the science teachers have the same level of self-efficacy;

- there are no differences between the Estonian and Russian-language instruction schools' science teachers' constructivist beliefs and self-efficacy;

- in comparison with the other subject teachers, the science teachers pay more attention to the student-centred practices in lower-secondary science lessons.

To answer these questions, empirical studies were carried out by means of quantitative secondary analyses of TALIS 2008 and TALIS 2013 data.

This study used Estonian data from TALIS 2008 which was collected from a total of 3321 teachers and from 598 science teachers. For this study, the science teachers were divided into two groups - Estonian language instruction school teachers $(N=513)$ and Russian language instruction school teachers $(N=85)$.

The next study used Estonian data from TALIS 2013 which was collected from 3129 teachers and from 837 science teachers. The science teachers were divided into three groups - Estonian language instruction school teachers $(N=665)$, Russian language instruction school teachers $(N=82)$ and school teachers in mixed language instruction schools $(N=90)$.

\section{The science teachers' pedagogical beliefs, self-efficacy and teaching practices}

Six TALIS 2008 teachers' beliefs and teaching variables/indices (efficacy, direct transmission beliefs, constructivist beliefs, structuring practices, student-oriented practices, enhanced teaching activities), three TALIS 2013 teachers' beliefs and constructivist learning indices (efficacy in classroom management; efficacy in instruction and student engagement; constructivist beliefs) and different TALIS 2013 teaching practices questions/items $(N=28)$ were selected for the analysis. The sub-set was needed because in TALIS 2013 the teaching indices had not been compiled and single items for analyses were used. 
Within the TALIS study, all items of questionnaires were measured on a four-point scale, where meaning of 1 was "not at all", 2 was "to some extent", 3 was "quite a bit", and 4 was "a lot" or 1 was "strongly disagree", 2 was "disagree", 3 was "agree" and 4 was "strongly agree" (OECD, 2009b, 2014b).

It appeared that the Estonian science teachers' perceptions of constructivist beliefs have not changed significantly in recent years. The secondary analysis of the 2008 and 2013 results revealed that science teachers' constructivist estimates were significantly higher than other Estonian teachers' estimates. The results confirm the other researchers' findings (Kikas, 2013) that the Estonian science teachers have gained the knowledge that constructivism is important to implement in the classroom, but they do not rely on it for everyday teaching. The Russian language instruction schools' science teachers support constructivist beliefs significantly less than in TALIS 2008.

The Estonian science teachers' estimates of self-efficacy in TALIS 2013 were significantly higher than in TALIS 2008, but in comparison with science teachers in the Estonian language instruction schools, the science teachers in the Russian language instruction schools claimed to be more effective in classroom management, in instruction and setting up, as well as student engagement.

The authors' TALIS 2008 analyses showed that in comparisons with other teachers, practices implemented by Estonian science teachers most frequently were structure-oriented teaching practices and less students' cognitive development-oriented practices.

The first hypothesis was confirmed. There was a significant difference between the other subject teachers and the science teachers' constructivist beliefs practices in TALIS 2013. The science teachers gave more support to constructivist beliefs. The second hypothesis was not confirmed. The science teachers' self-efficacy estimates were significantly higher.

The third hypothesis was not confirmed. There were significant differences between the science teachers in Estonian and Russian-language instruction schools in respect of constructivist beliefs and self-efficacy. The Estonian-language instruction schools' science teachers' constructivist estimates were significant higher and self-efficacy estimates lower.

The fourth hypothesis was not confirmed. The statistically significant differences between the science and the other teachers' estimates were not observed in the implementation of active teaching practices. In comparisons with estimates by other subject teachers, the science teachers paid no more attention to students' active practices in lower-secondary science lessons. 
The TALIS 2013 analyses (OECD, 2014b) revealed that science teachers frequently claimed that their role as a teacher was to facilitate students' own inquiry, but at the same time, they reported that they paid less attention to the development of students' motivation.

The study confirmed the previous studies' findings that the Russian school science teachers gave more positive feedback and that this feedback was controversial (Henno, 2015).

It seems that the Estonian science teachers' perceptions of constructivist beliefs have not changed significantly in recent years as it appeared to, and also that Estonian science teachers' frequency of estimates about the implementation of inquiry-based instructional practices (even they support constructivist view of teaching and learning) were low. These results may be linked with the PISA 2015 findings. The PISA findings showed that only 9\% of Estonian students (OECD average 21\%) reported that they are allowed to design their own experiments or spend time in the laboratory doing practical experiments (OECD, 2016).

Given the Estonian science teachers' need to implement the National Curriculum and change the new approach to teaching and learning, based on their perceptions, we can claim, that the Estonian science teachers do not sufficiently encourage students to be deep learners and to inquire about a science problem using scientific methods, including experiments.

To sum up, it can be said that there are needs for methodical materials and in-service training and important changes should be made to the training of teachers in Russian language instruction schools. This topic is very urgent and needs to be addressed in further studies.

Keywords: science teachers' constructivist beliefs, teaching practices in science, TALIS 2008 and 2013, science teaching in Estonian lowersecondary school 